\title{
Improving Methane Production through Co-Digestion of Canola Straw and Buffalo Dung by $\mathrm{H}_{2} \mathrm{O}_{2}$ Pretreatment
}

\author{
ALTAF ALAM NOONARI*, RASOOL BUX MAHAR**, ABDUL RAZAQUE SAHITO* AND \\ KHAN MUHAMMAD BROHI* \\ RECEIVED ON 09.06.2016 ACCEPTED ON 16.08.2016 \\ ABSTRACT
}

\begin{abstract}
In this study an effect of acidic pretreatment on the CS (Canola Straw) and BD (Buffalo Dung) by anaerobic co-digestion was investigated. $\mathrm{H}_{2} \mathrm{O}_{2}$ (Hydrogen Peroxide) is a mainly accustomed reagent, used as a bleaching agent in the different industries such as paper and wood. In the present study, it was used as a pretreatment chemical at varying concentrations in batch reactors. The co-digestion of CS and BD was carried out in SAMPTS (Semi-Automatic Methane Potential Test System) at mesophilic $\left(37 \pm 1^{\circ} \mathrm{C}\right.$ ) conditions. The CS was pretreated in glass bottles with different concentrations of the $\mathrm{H}_{2} \mathrm{O}_{2}$ for seven days. The inoculum used in the present study was an effluent of the CSTR (Continuous Stirred Tank Reactor), which was treating BD at mesophilic conditions. The specific methane production from the codigestion of canola straw and $\mathrm{BD}$, by the pretreatment of $\mathrm{H}_{2} \mathrm{O}_{2}$ at concentrations of $0.5,1.0$, and $1.5 \%$ were 530.8, 544.5, and 510.3 $\mathrm{NmLCH}_{4} \mathrm{~g} / \mathrm{VS}$, respectively. The significant reduction in the volatile solids of CS was observed at the optimum pretreatment of $1.0 \% \mathrm{H}_{2} \mathrm{O}_{2}$.
\end{abstract}

Key Words: Anaerobic Co-Digestion, Hydrogen Peroxide, Optimization, Methane.

\section{INTRODUCTION}

1

D (Anaerobic Digestion) process plays a significant role in the degradation of the organic material in absence of oxygen. Through AD process generated energy is biogas [1-2]. The biogas includes a variety of gases, from them predominantly methane and carbon dioxide takes leading position and among the few trace gases [3]. The AD process generally describes as four stages, namely hydrolysis, acidogenesis, acetogenesis and lastly methanagesis [4]. Initially, the AD technology was started for sewage sludge and animal waste. Later on it is being used for treating the variety of the organic materials including the crop residues. In order to improve the potential process, the digester use the co-digestion process by adding them two or more types of feedstock. The animal waste (BD) and crop residue using as codigestion for renewable energy has tremendous advantages such as greenhouse neutral fuel, alternative of fossil fuels, and applicable for cooking, heating and generation of electricity. Moreover, it represents a feasible and effective waste-stabilization method to convert the undiluted solid bio-waste into nutrient rich organic fertilizer [5]. An important cause for the two or more digestion to substrate is the adjustment of $\mathrm{C} / \mathrm{N}$ (Carbon

* Institute of Environmental Engineering \& Management, Mehran University of Engineering \& Technology, Jamshoro.

** US-Pakistan Centres for Advanced Studies in Water, Mehran University of Engineering \& Technology, Jamshoro.

Mehran University Research Journal of Engineering \& Technology, Volume 36, No. 1, January, 2017 [p-ISSN: 0254-7821, e-ISSN: 2413-7219] 
to Nitrogen) ratio [6]. Animal manure, especially BD is a low-cost substrate having various carbohydrates, a very good ratio of $\mathrm{C} / \mathrm{N}$, excellent microbial flora, and become a useful source of biogas [7]. The $\mathrm{C} / \mathrm{N}$ of $\mathrm{BD}$ is reasonable as compared to crop residues, while the co-digestion stabilize the $\mathrm{C} / \mathrm{N}$ ratio and thus reduces the threat of ammonia inhibition [1]. Generally, crops are lignocellulosic substance and composed of three dissimilar polymers such as lignin, cellulose and hemicellulose as shown in Fig. 1.

The lignin is very difficult to degrade in the AD process. It is a shield to protect cellulose and hemicellulose, and thus improves the mechanical strength of cell wall [9]. The lignin present in the organic material can be breakdown by using different pretreatments. Pretreatments may be physical, chemical, thermal, biological or the combination of more than one [10]. The $\mathrm{H}_{2} \mathrm{O}_{2}$ is an acidic reagent used as bleaching agent in the different industries such as paper and wood. Numerous fact finders recently highlighted that acidic pretreatment, especially $\mathrm{H}_{2} \mathrm{O}_{2}$ could be used as for the AD process because of its vigorous oxidizing ability [5]. Beside this, $\mathrm{H}_{2} \mathrm{O}_{2}$ is also cheap acidic chemical in comparison to $\mathrm{H}_{2} \mathrm{SO}_{4}$ and $\mathrm{HCl}$ and can be used to improve the degradation of the organic process [11].

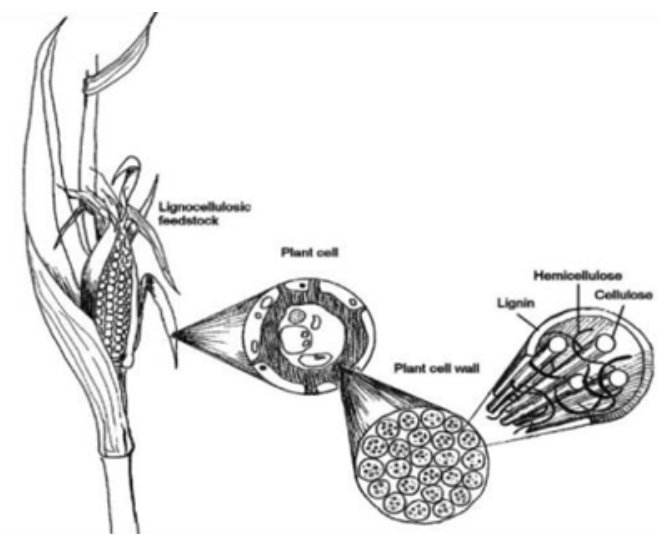

FIG. 1. STRUCTURE OF LIGNOCELLULOSE COMPLEX IN PLANT CELL WALLS [8]
A number of researchers highlighted that the $\mathrm{AD}$ applied in a different range of temperatures from $5-60^{\circ} \mathrm{C}$. Generally three common names are as follows psychrophilic $\left(<20^{\circ} \mathrm{C}\right)$, mesophilic $\left(>20^{\circ} \mathrm{C}\right.$ to $\left.>40^{\circ} \mathrm{C}\right)$ and last thermophilic $\left(>60^{\circ} \mathrm{C}\right)$ [12]. Most microbes are active in the last two categories of temperature ranges, and thus are important regarding the fermentation time period [13]. The mesophilic temperature comes in ideal because of maximum biogas production, especially when the temperature is maintained around $37^{\circ} \mathrm{C}[14]$.

Literature finds that the methane production from wheat straw, rice straw, corn straw and cotton stalks can be improved by using acidic and alkaline concentrations through pretreatments. Pakistan is an agricultural country and every year it generates different types of crop in huge amount it includes canola, rice, cotton, banana and wheat, etc. These crops produce bulk quantities of field residues annually. Most of the field residues are wasted. One of the solution is to utilize these crop residues with animal dung as co-digestion substrate not to produce the energy, but also to overcome the environmental problems [15].

The prime aim of the present study was to improve methane production through co-digestion of $\mathrm{CS}$ and $\mathrm{BD}$ using co-digestion in mesophilic condition by anaerobically under batch experiments. In the present work, optimum CS to BD ratio on the basis of VS (Volatile Solids) (40:60) and optimum particle size of CS (4mm) was considered as an output from the previous study of Sahito, et. al. [9].

\section{MATERIALS AND METHOD}

\subsection{Raw Material and Inoculum}

Fresh BD was collected near the Sindh University Railway Station, Jamshoro, and CS were obtained canola field from the Union Council Hatri, District Hyderabad. The size of

Mehran University Research Journal of Engineering \& Technology, Volume 36, No. 1, January, 2017 [p-ISSN: 0254-7821, e-ISSN: 2413-7219] 
CS was reduced up to $4 \mathrm{~mm}$ by using hammer mill, which was fitted with the desired $4 \mathrm{~mm}$ perforated plate. The prepared sample was kept in nylon bags at room temperature until use of pretreatment to BMP (Biochemical Methane Potential) test. In the present study, an effluent from CSTR treating BD was used as the inoculum. The CSTR was operating at $37 \pm 1^{\circ} \mathrm{C}$, whereas the initial $\mathrm{pH}$ of the inoculum was $7.0 \pm 0.1$.

\subsection{Experimental Setup of Pretreatments}

In order to get better methane potential from $\mathrm{H}_{2} \mathrm{O}_{2}$ pretreatment, the different $0.5,1.0$ and $1.5 \%$ concentrations were used and the experiment was conducted according to Song et. al. [5]. On the basis of the VS, the CS was kept in glass bottles with $\mathrm{H}_{2} \mathrm{O}_{2}$ chemical for seven days for enhancing the methane production. After this the fresh buffalo dung was added in glass bottles without any pretreatment. To measure methane production, the SAMPTS was used which is lab experimental setup.

\subsection{Preparation and Operation of Batch Test}

The $500 \mathrm{~mL}$ borosilicate glass working bottles were used as reactors and the BMP assays were prepared in duplicates, which was operated at the temperature of $37 \pm 1^{\circ} \mathrm{C}$. All reactor bottles were load to $5 \mathrm{~g}$ of VS, i.e. mixture of CS and BD with $0.5,1.0$ and $1.5 \%$ respectively whereas last two were the control. The $\mathrm{pH}$ was adjusted to $7.0 \pm 0.1$ by neutralizing reagents and the inoculum $50 \mathrm{~mL}$ was also add in co-digested reactors then all were filled up to $400 \mathrm{~mL}$ of volume and were hermetically sealed with rubber stoppers [9]. With the help of electric motors attached with mechanically bent stir rod the substrate were intermittently mixed set a speed of $70 \mathrm{rpm}$ which run for 1 minute after every 30 minutes [17]. Before start the batch, in each reactor bottle nitrogen was purged up to 5 minutes to remove oxygen and create the full anaerobic condition in all reactors [18].

\subsection{Analysis and Calculations}

The pH, MC (Moisture Content), TS (Total Solids), VS, TA (Total Alkalinity), and VFA (Volatile Fatty Acid) were determined according to the APHA (American Public Health Association) Standard Methods [5]. The VFA determined by distillation, whereas the TA was titration methods respectively [1]. The volume of methane produced from each digester was recorded daily and each batch experiment were performed 40 days. The entire setup of the SAMPTS is shown in Fig. 2.

\section{RESULTS AND DISCUSSION}

\subsection{Effect of Different Concentrations on Feedstock}

The main objective of the present study was to enhance the methane production and change the substrate's properties of co-digestion through pretreatments. After 40 days of batch digestion, the results of chemical analysis, i.e. MC, TS and VS were calculated as per standard methods on dry weight basis and are given in Table 1. CS was pretreated with different concentrations in $\mathrm{H}_{2} \mathrm{O}_{2}$ similar to Song, et. al. [19]. In AD reactor, the TA, $\mathrm{pH}$ and VFA are the main parameters for determination of inhibition. The role of TA is to avoid the $\mathrm{pH}$ variation, which decreases due to accumulation of VFA and increase

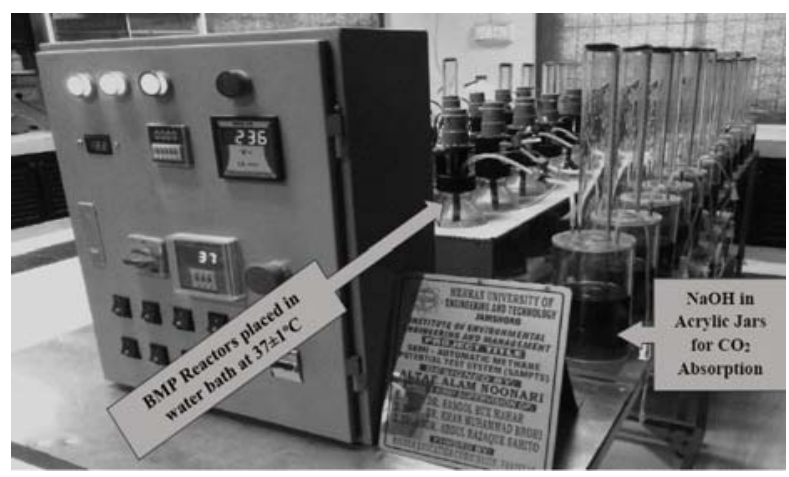

FIG. 2. SEMI-AUTOMATIC METHANE POTENTIAL TEST SYSTEM (SAMPTS)

Mehran University Research Journal of Engineering \& Technology, Volume 36, No. 1, January, 2017 [p-ISSN: 0254-7821, e-ISSN: 2413-7219] 
because of the accumulation of the ammonia [20]. The alkalinity range of $1800-2000 \mathrm{mg} \mathrm{CaCO} / \mathrm{L}$ indicates the process of digestion is stable. When the ratio of VFA to TA is 0.5 then $A D$ system is reliable, but if the ratio exceeds the limit of 0.5 it considered the indication of instability of digester [21].

At the end of 40 days of batch digestion, samples were analyzed for TA, VFA and $\mathrm{pH}$. In these results $\mathrm{pH}$ samples were within the range except $1.5 \% \mathrm{H}_{2} \mathrm{O}_{2}$, i.e. 5.7-5.9, which shows the toxicity of the $\mathrm{AD}$ process. The TA was in the range of $300-1150 \mathrm{mg} \mathrm{CaCO}_{3} / \mathrm{L}$. The varying values of VFA, i.e. $300-720 \mathrm{mg} \mathrm{CH}_{3} \mathrm{COOH} / \mathrm{L}$ were observed due to the $\mathrm{H}_{2} \mathrm{O}_{2}$ is an acidic in nature. The ratio of VFA to alkalinity of all concentrations were also determined as given in Table 2. Results showed that $\mathrm{H}_{2} \mathrm{O}_{2}$ pretreatment with different concentrations were supplementary powerful in disintegrated of lignocellulose material.

TABLE 1. CHEMICAL ANALYSIS OF CO-DIGESTION AFTER PRETREATMENT (DRY BASIS)

\begin{tabular}{|c|c|c|c|c|}
\hline \multirow{2}{*}{ Substrate } & \multirow{2}{*}{ Control } & \multicolumn{3}{|c|}{$\mathrm{H}_{2} \mathrm{O}_{2}$} \\
\cline { 3 - 5 } & & $0.5(\%)$ & $1.0(\%)$ & $1.5(\%)$ \\
\hline $\mathrm{pH}$ & 6.9 & 7 & 6.8 & 5.8 \\
\hline $\mathrm{MC}(\%)$ & 99.21 & 98.94 & 98.92 & 98.76 \\
\hline $\mathrm{TS}(\%)$ & 0.79 & 1.06 & 1.08 & 1.24 \\
\hline $\mathrm{VS}(\%)$ & 73.64 & 75.98 & 79.4 & 80.76 \\
\hline $\mathrm{AC}(\%)$ & 26.37 & 24.02 & 20.6 & 19.24 \\
\hline
\end{tabular}

TABLE 2. RESULTS OF TA AND VFA OF CO-DIGESTION AFTER PRETREATMENT

\begin{tabular}{|c|c|c|c|c|}
\hline \multirow{2}{*}{ Substrate } & \multirow{2}{*}{ Control } & \multicolumn{3}{|c|}{$\mathrm{H}_{2} \mathrm{O}_{2}$} \\
\cline { 3 - 5 } & & $0.5(\%)$ & $1.0(\%)$ & $1.5(\%)$ \\
\hline $\mathrm{TA}\left(\mathrm{mg} \mathrm{C}_{\mathrm{a}} \mathrm{CO}_{3} / \mathrm{L}\right)$ & 575 & 1000 & 1000 & 325 \\
\hline $\begin{array}{c}\mathrm{VFA}(\mathrm{mg} \\
\left.\mathrm{CH}_{3} \mathrm{COOH} / \mathrm{L}\right)\end{array}$ & 270 & 510 & 480 & 630 \\
\hline $\mathrm{VFA} / \mathrm{TA}$ & 0.47 & 0.51 & 0.48 & 1.94 \\
\hline
\end{tabular}

Song, et. al. [5] indicated that rice straw was greatly influenced to decompose the three key parameters, i.e. lignin, cellulose and hemicellulose by acidic pretreatment. Sahito, et. al. [16] concluded that alkaline pretreatment gives 13\% higher removal levels of rice straw, regardless of the mesophilic temperature. In the present study, by varying concentrations of acidic pretreatments had different effects on lignocellulosic composition. The acidic pretreatment found that disruption of hydrogen bonds, covalent bond and Van der Waals forces that hold together the biomass components. On the other hand, alkali pretreatment break the links between lignin monomers and polysaccharides that makes the lignocelluloses swell through saponification reactions [19].

\subsection{Ultimate Cumulative Methane Production of $\mathrm{H}_{2} \mathrm{O}_{2}$ Pretreatment}

The ultimate cumulative methane production from the codigestion of CS along with the BD was 530.8, 544.5, and $510.3 \mathrm{NmL}$ on the pretreated of $\mathrm{H}_{2} \mathrm{O}_{2} 0.5,1.0$, and $1.5 \%$, respectively. Besides, the control BD yields only 480.1 $\mathrm{NmL}$ as shown in Fig. 3. In batch reactor, the methane generation was started from day one and was fluctuating due to the interaction of different phases of the AD Process. The $\mathrm{H}_{2} \mathrm{O}_{2}$ pretreatment having $1.0 \%$ concentration resulted highest methane production, i.e. $544.5 \mathrm{NmLCH}_{4} / \mathrm{gVS}$ than the other concentrations. These results were observed $68.9 \%$ more than from the results of Sahito, et. al. [8]. Moreover, these results are higher than the results of Song, et. al. [18] for digesting the corn straw after pretreatment with the $\mathrm{H}_{2} \mathrm{O}_{2}$. The results of the present study are in agreement with Song, et. al, [5] and shows that on an increase the acidic doze, the pretreatment was harmful for methanogens in respect of toxicity. Thus, $1.0 \% \mathrm{H}_{2} \mathrm{O}_{2}$ was designated that the most suitable concentration of $\mathrm{CS}$ and $\mathrm{BD}$ for enhancing the methane production.

Mehran University Research Journal of Engineering \& Technology, Volume 36, No. 1, January, 2017 [p-ISSN: 0254-7821, e-ISSN: 2413-7219] 
Several pretreatment studies are available in the literature, which are related to different kinds of organic materials. Regarding the residues of crops, Song et. al. [19] had used $\mathrm{H}_{2} \mathrm{O}_{2}$ pretreatment on the corn straw followed by its anaerobic digestion and revels that maximum methane was obtained at $3 \%$ pretreatment of $\mathrm{H}_{2} \mathrm{O}_{2}$. Moreover, Silverstein et al. [22] reported that cotton stalks pretreated by $\mathrm{H}_{2} \mathrm{O}_{2}$ results highest deligniûcation of cellulose of $49.8 \%$.
The methane flow rates are shown in Fig. 4. As per the results, the methane flow rate considerably decreases after 30 days of digestion. Furthermore, it indicates that $\mathrm{H}_{2} \mathrm{O}_{2}$ pretreatment effectively improve the biodegradability, and thus the output of methane was improved. The methane yield was analyzed with the help of a Gas Chromatograph (Shimadzu, Model GC-2010) installed with a thermal conductivity detector.

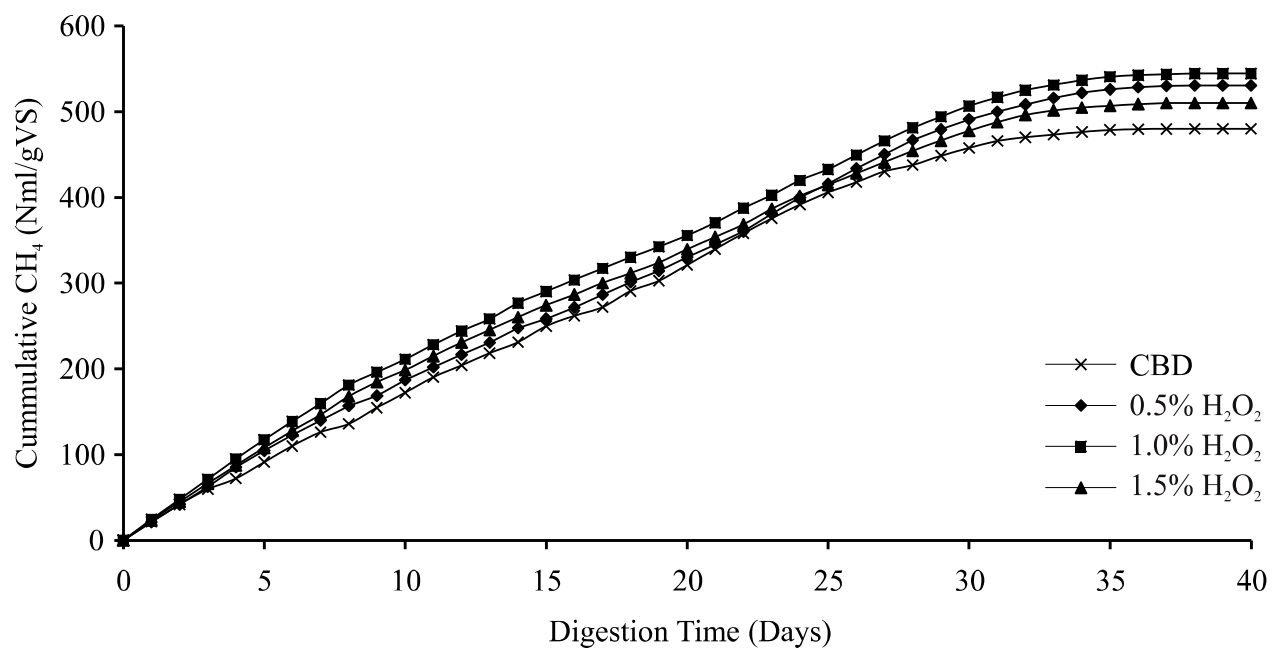

FIG. 3. CUMULATIVE METHANE PRODUCTION OF CS AND BD OF $\mathrm{H}_{2} \mathrm{O}_{2}$ PRETREATMENT WITH DIFFERENT CONCENTRATIONS WHEREAS CBD: CONTROL OF THE BUFFALO DUNG

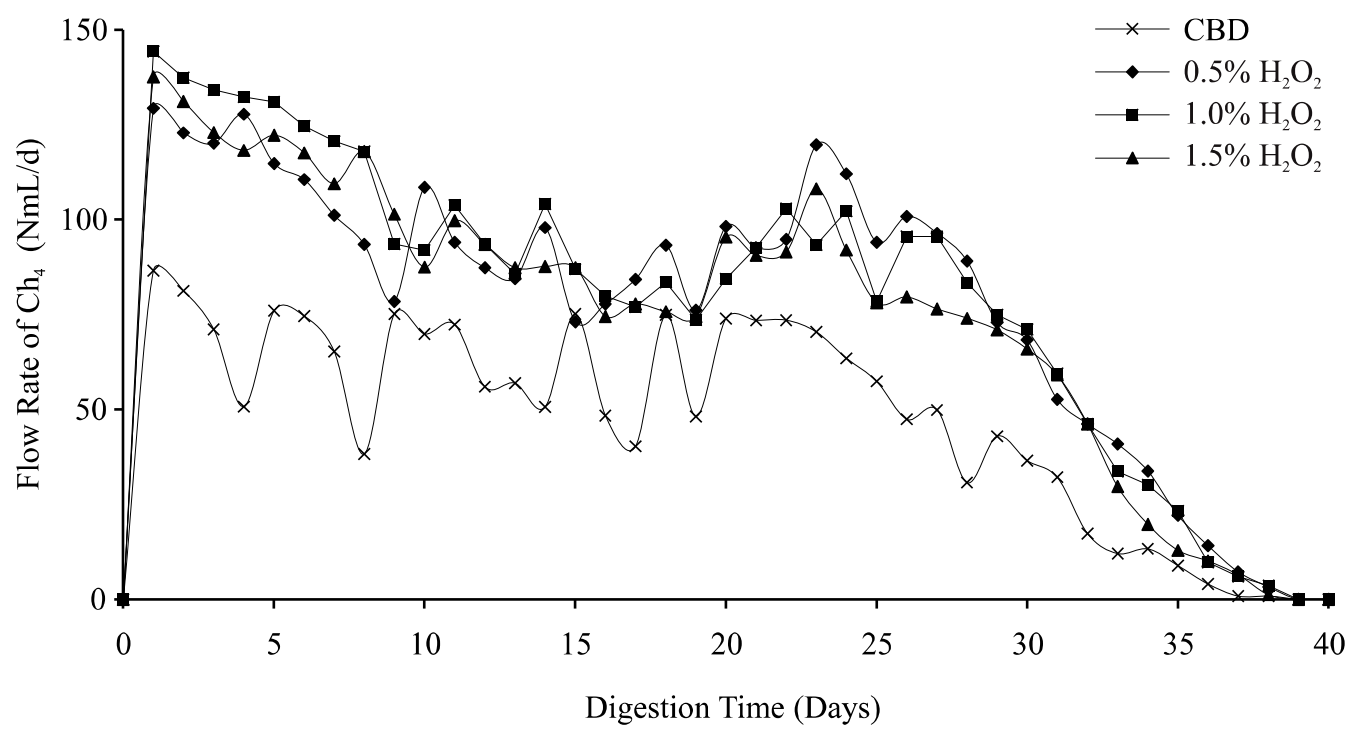

FIG. 4. METHANE FLOW RATE OF CS AND BD OF $\mathrm{H}_{2} \mathrm{O}_{2}$ PRETREATMENT WITH DIFFERENT CONCENTRATIONS WHEREAS CBD: CONTROL OF THE BUFFALO DUNG

Mehran University Research Journal of Engineering \& Technology, Volume 36, No. 1, January, 2017 [p-ISSN: 0254-7821, e-ISSN: 2413-7219] 
In batch reactor, the methane generation was started from the first day and was increased from all three different concentrations of $\mathrm{H}_{2} \mathrm{O}_{2}$ pretreatment. The fluctuations were observed several times before the end of BMP test. The $0.5 \%$ concentration reached its peak value $108 \mathrm{NmL}$ at (day 10) whereas the 120 (day 23), and 101 (day 26) were obtained. A same trend was also observed for the 1.0 and $1.5 \%$ concentrations, peak values $104 \mathrm{NmL}$ (day 14), 102 (day 24) and 108 (day 23), respectively. After 30 days of digestion, the methane flow rate considerably decreased, because of feedstock concentration was not as much as the initial concentration. The $1.0 \%$ concentrated $\mathrm{CS}$ at the beginning stage of $\mathrm{AD}$ gives optimal organic acid for the methanogen, which helps the growth of methanogen and resulted in an enhanced methane production [5].

\subsection{Effect of Different Concentrations on VS Reduction}

Methane yield can be obtained from the conversion of feedstock and mostly determined by reductions in the VS. In the present study, acidic pretreatment 56.67 and $57.53 \%$ VS reduction was acquired than the single control samples. This result was in agreement with findings of Song, et. al. [19]. Moreover, the CS obtained a higher VS reduction than the control. The VS reductions in the $\mathrm{CS}$ and $\mathrm{BD}$ was calculated by using Equation (1).

$\mathrm{VS}_{\text {red }}=\frac{\left(1-\mathrm{VS}_{\text {out }}\right)}{\mathrm{VS}_{\mathrm{in}}} \times 100$

In order to compare the eûectiveness of acid pretreatment, the efficiency of a pretreatment is not only based on the production of methane, but also based on the other parameters. The $\mathrm{H}_{2} \mathrm{O}_{2}$ pretreatment was more effective and easier to use because of solubilizing in water and a less effort for the adjustment of the $\mathrm{pH}$. It was also cheaper than the other acidic chemicals like $\mathrm{H}_{2} \mathrm{SO}_{4}, \mathrm{HCl}$, etc.

\section{CONCLUSIONS}

In the present study, the concentration of $\mathrm{H}_{2} \mathrm{O}_{2}$ was optimized for the maximum production of the methane from the co-digestion of $\mathrm{CS}$ and BD. CS, which was difficult to biodegrade by AD because of high lignin content, degrades well with the chemical pretreatment. The results yield that co-digestion pretreated with $1.0 \% \mathrm{H}_{2} \mathrm{O}_{2}$ generate the highest methane yield of $544.5 \mathrm{NmL} \mathrm{CH}_{4} \mathrm{~g} / \mathrm{VS}$.

In order to improve the efficiency of $\mathrm{AD}$, the effect of alkaline pretreatment at different concentrations may be carried out in future.

\section{ACKNOWLEDGEMENTS}

Authors are thankful to Higher Education Commission, Islamabad, Pakistan, for research funded project named optimization of anaerobic digestion process using codigestion of crop residues and buffalo dung. Authors also grateful to Mehran University of Engineering \& Technology, Jamshoro, Sindh, Pakistan, for its support to carry out this research work.

\section{REFERENCES}

[1] Sahito, A.R., Mahar, R.B., and Brohi, K.M., "Anaerobic Biodegradability and Methane Potential of Crop Residue Co-Digested with Buffalo Dung”, Mehran University Research Journal of Engineering \& Technology, Volume 32, No. 3, [ISSN 0254-7821], Jamshoro, Pakistan, July, 2013.

[2] El-Mashad, H.M., and Zang, R., "Biogas Production from Co-Digestion of Dairy Manure and Food Waste", Bioresource Technology, Volume 101, pp. 4021-4028, 2010 . 
[3] Ilaboya, I.R., Asekhame, F.F., Ezugwu, M.O., Erameh, A.A., and Omofuma, F.E., "Studies on Biogas Generation from Agricultural Waste; Analysis of the Effects of Alkaline on Gas Generation", World Applied Sciences Journal, Volume 9, No. 5, pp. 537-545, 2010.

Peter, W., "Biogas Production: Current State and Perspectives", Applied Microbiology Biotechnology, Volume 85, pp. 849-860, 2010.

Song, Z., Yang, G., Guo, Y., and Zhang, T., "Comparison of Two Chemical Pretreatments of Rice Straw for Biogas Production by Anaerobic Digestion", Bio-Resources, Volume 7, No. 3, pp. 3223-3236, 2012.

Ward, A.J., Hobbs, P.J., Holliman, P., and Jones, D.L., "Optimization of the Anaerobic Digestion of Agricultural Resources", Bio Resource Technology, Volume 99, pp. 7928-7940, 2008.

Carillo, P., Carotenuto, C., Cristofaro, D.F., Kafantaris, I., Lubritto, C., Minale, M., Morrone, B., Papa, S., and Woodrow, P., "DGGE Analysis of Buffalo Manure Eubacteria for Hydrogen Production: Effect of $\mathrm{pH}$, Temperature and Pretreatments", Mol. Biology Report, Volume 39, pp. 10193-10200, 2012.

[8] Lucy, F.R.M., and Günther, B., "Pretreatment of Feedstock for Enhanced Biogas Production", Technical Brochure, IEA Bioenergy, [ISBN 978-1-910154-05-2], 2014.

[9] Sahito, A.R., Mahar, R.B., and Brohi, K.M., "Anaerobic Co-Digestion of Canola Straw and Buffalo Dung: Optimization of Methane Production in Batch Experiments", Mehran University Research Journal of Engineering \&Technology, Volume 33, No. 1, [ISSN 0254-7821], Jamshoro, Paksitan, January, 2014.

[10] Xie, S., Frost, J.P., Lawlor, P.G., Wu, G., Zhan, X., "Effects of thermo-chemical pre-treatment of grass silage on methane production by anaerobic digestion", Bioresource Technology, Volume 102, pp. 8748-8755, 2011.
[11] Li, L., Chen, C., Zhang, R., He, Y., Wang, W., and Liu, G., "Pretreatment of Corn Stover for Methane Production with the Combination of Potassium Hydroxide and Calcium Hydroxide", Energy \& Fuels, Volume 29, No. 9, pp. 5841-5846, 2015.

[12] Zupancic, G.D., and Garlic, V., "Anaerobic Treatment and Biogas Production from Organic Waste", Management of Organic Waste, pp.1-2, 2012.

[13] Gerardi, M.H., "The Microbiology of Anaerobic Digesters, Waste Water Microbiology Series Hoboken”, John Wiley \& Sons, Inc., New Jersey, 2003.

[14] Manyi-Loh, C.E., Mamphweli, S.N., Meyer, E.L., Okoh, A.I., Makaka, G., and Simon, M., "Microbial Anaerobic Digestion (Bio-Digesters) as an Approach to the Decontamination of Animal Wastes in Pollution Control and the Generation of Renewable Energy", International Journal of Environmental Research and Public Health, Volume 10, pp. 4390-4417, 2013.

[15] Mahar, R.B., Sahito A.R., and Uqaili, M.A., "BioMethanization Potential of Waste Agricultural Biomass in Pakistan: A Case Study", International Journal of Biomass \& Renewables, Volume 1, pp. 32-37, 2012.

[16] Sahito, A.R., and Mahar, R.B., "Enhancing Methane Production From Rice Straw Co-Digested With Buffalo Dung by Optimizing Effect of Substrate Ratio Alkaline Doze and Particle Size", The Journal of Animal and Plant Sciences, Volume 24, No. 4, pp. 1076-1084, [ISSN: 1018-7081], 2014.

[17] Abubakar, I.B.S.U., and Ismail, N., "Anaerobic Digestion of Cow and Dung for Biogas Production", Journal of Engineering \& Applied Sciences, Volume 7, No. 2, pp. 196-172, 2012.

[18] Zhao, Q., Leonhardt, E., MacConnell, C., Frear, C., and Chen, S., "Purification Technologies for Biogas Generated by Anaerobic Digestion”, CSANR Research Report-001, 2010. 
[19] Song, Z., Yang G., Liu, X., Yan, Z., Yuan, Y., and Liao, Y., "Comparison of Seven Chemical Pretreatments of Corn Straw for Improving Methane Yield By Anaerobic Digestion”, PLOS ONE, Volume 9, No. 4, 2014.

Lesteur, M.V., Bellon-Maurel, C., Gonzalez, E., Latrille, J.M., Roger, G.J., and Steyer, J.P., "Alternative Methods for Determining Anaerobic Biodegradability: A Review", Process Biochemistry, Volume 45, pp. 431-440, 2010.
[21] Lin, Y.Q., Wang, D.H., Wu, S.Q., and Wang, C.M., "Alkali Pretreatment Enhances Biogas Production in the Anaerobic Digestion of Pulp and Paper Sludge", Journal Haze. Mat, Volume 170, No. 1, pp. 366-373, 2009.

[22] Silverstein, A.R., Chen, Y., Shivappa, S.R., Boyette, M.D., and Osborne, J., "A Comparison of Chemical Pretreatment Methods for Improving Saccharification of Cotton Stalks", Bioresource Technology, Volume 98, No. 16, pp. 3000-3011, 2007. 